\title{
Applications and Implications of Viral and Non Viral Vectors in
}

\section{Gene Therapy}

Veerareddy $\mathrm{PR}^{*}$

Palamuru University, India

*Corresponding author: Prabhakar Reddy Veerareddy, University College of

Pharmaceutical Sciences, Palamuru University, Mahabubnagar, Telangana State,

India, Email: vpreddyindia@gmail.com

\section{Editorial}

Volume 3 Issue 2

Received Date: May 13, 2019

Published Date: May 17, 2019

DOI: 10.23880 /oajpr-16000176

\section{Editorial}

Gene therapy is a new technique which uses genes to treat or prevent diseases. Viruses normally possess strong promoters, which can create high level gene expression in the infected host cells. Gene Therapy is recognized by the mammalian viruses that are offered as potential tool for gene delivery by either as a biological device or as a vehicle to treat the genetic diseases [1]. Gene therapy involves with Adenovirus, Herpes Simplex Virus, Vaccinia Virus vectors and is utilized in the clinical studies. These vectors are generally nonintegrating and not associated with a known risk of genotoxicity. Adenoviruses are with a double-stranded genome to encode genes with both the sense and antisense orientations [2]. Herpes Simplex Virus (HSV) is an enveloped virus with a double-stranded DNA genome is divided in to long and short unique segments and flanked by sequences [3]. Vaccinia Virus is a linear double stranded DNA genome which was used in the eradication of smallpox [4]. Adeno Associated Virus (AAV) vectors have demonstrated the safety in the clinical trials for canavan's disease [5]. More than 65\% of clinical trials of gene therapy were focused on cancer indications [6]. Retroviruses are the double stranded RNA viruses possessing reverse transcriptase activity, which enables them to integrate as DNA copies in the host genome [7]. In vivo gene therapy studies with Baculo virus vectors were conducted in the rabbit carotid artery [8] and rat brain [9]. Patient with partial ornithine trans carbamylase (OTC) deficiency who participated in a pilot study died after a hepatic arterial injection of the adeno viral vector [10]. The pox virus vectors were used to immunize against herpes, hepatitis $\mathrm{B}$, rabies, influenza, HIV and other viruses [11]. Retroviral vectors are widely used in both cell biology and biomedicine [12]. Biosafety
Considerations for research with Lentiviral Vectors published by the U.S. National Institutes of Health (NIH)'s Recombinant DNA Advisory Committee [13]. Vaccines based on Lentiviral vector were developed against HIV infection [14]. Gene therapy of somatic cell is suitable and adequate for many disorders [15]. The transplanted gene is injected in the exact site in the infected person, then it can give instructions for creating particular proteins [16]. Gene doping might be harmed to improve athletic performance [17]. Invention of gene therapy techniques will be able to achieve a great success in the current science [18]. Small interfering RNA (siRNA) technology has been used to silence a mutated gene which is activated or over expressed in cancer cells [19]. Oncolytic viruses selectively replicate the cancer cells foremost to tumor cell damage and oncolysis [20]. The high transfection efficiency with adenovirus in vitro is effective, but, in in vivo, its not effective in solid tumor models [21]. Gestational diabetes is the common type of Diabetes Mellitus is linked with pregnancy, without earlier history of diagnosis of Diabetes Mellitus, it may develop to Type2 Diabetes Mellitus after pregnancy [22]. Encapsulations with biomaterials are another way to pack the genetic material [23]. The first successful clinical trial with engineered plasmid expressing proinsulin as gene-based Type1 Diabetes Mellitus therapy was Performed [24]. A different Selection of molecular tools was applied to produce vectors with immune avoidance properties [25]. In recombinant Adeno Associated Virus vectors, the genes are deleted and replaced with a therapeutic gene [26]. Rogers and Pfuderer demonstrated the proof of concept for virus-mediated gene transfer by using the tobacco mosaic virus [27]. Glybera (alipogene tiparvovec) is a first 


\section{Open Access Journal of Pharmaceutical Research}

commercial gene therapy product approved in Europe for the treatment of Lipoprotein lipase deficiency [28]. In the clinical studies, following intra muscular administration of Glybera, peak levels of vector DNA were detected in serum, saliva and urine [29]. 213 gene therapy products are in clinical development by worldwide [30]. In the future, this technique may allow doctors to treat a disorder by inserting a gene into a patient's cells instead of using drugs or surgery.

\section{References}

1. Mann R, Mulligan RC, Baltimore D (1983) Construction of a retrovirus packaging mutant and its use to produce helper-free defective retrovirus. Cell 33(1): 153-159.

2. Tatsis N, Ertl HCJ (2004) Adenoviruses as vaccine vectors. Mol Ther 10(4): 616-629.

3. Manservigi R, Argnani R, Marconi P (2010) HSV recombinant vectors for gene therapy. Open Virol J 4: 123-156.

4. Smith GL, Law M (2004) The exit of vaccinia virus from infected cells. Virus Res. 106(2): 189-197.

5. Mc Phee SWJ, Janson CG, Li C, Samulski RJ, Camp AS, et al. (2006) Immune responses to AAV in a phase I study for Canavan disease. J Gene Med 8(5): 577-588.

6. (2013) Gene Therapy Clinical Trials Worldwide. J Gene Med.

7. Kaleko M, Garcia JV, Miller AD (1991) Persistent Gene Expression After Retroviral Gene Transfer into Liver Cells In Vivo. Hum Gene Ther 2: 27-32.

8. Airenne KJ, Hiltunen MO, Turunen MP, Turunen AM, Laitinen OH. et al. (2000) Baculo virus Mediated Periadventitial Gene Transfer to Rabbit Carotid Artery. Gene Ther 7(17): 1499-1504.

9. Lehtolainen P, Tyynela K, Kannasto J, Airenne KJ, YlaHerttuala S (2002) Baculoviruses Exhibit Restricted Cell Type Specificity in Rat Brain: Comparison of Baculovirus- and Adenovirus-mediated Intracerebral Gene Transfer In Vivo. Gene Ther 9(24): 1693-1699.

10. Raper SE, Chirmule N, Lee FS, Wivel NA, Bagg A, et al. (2003) Fatal systemic inflammatory response syndrome in a ornithine trans carbamylase deficient patient following adenoviral gene transfer. Mol Genet Metab 80(1-2): 148-158.
11. Walsh SR, Dolin R (2011) Vaccinia viruses: vaccines against smallpox and vectors against infectious diseases and tumors. Expert Rev Vaccines 10(8): 1221-1240.

12. Buchschacher GL Jr (2001) Introduction to retroviruses and retroviral vectors. Somat Cell Mol Genet 26(6): 1-11.

13. oba.od.nih.gov/oba/rac/Guidance/LentiVirus_Contai nment/pdf/Lenti_Containment_Guidance.pdf

14. Lemiale F, Korokhov N (2009) Lentiviral vectors for HIV disease prevention and treatment. Vaccine 27(25-26): 3443-3449.

15. Bank A (1996) Human Somatic Cell Gene Therapy. BioEssays 18(12): 999-1007.

16. Walther W, Stein U (2000) Viral vector for gene transfer: a review of their use in the treatment of human disease. Drugs 60(2): 249-271.

17. (2013) Gene Doping. WADA.

18. Gene Therapy

19. Jones E, Dahm-Vicker M, Simon AK, Green A, Powrie F, et al. (2002) Depletion of CD25+ regulatory cells results in suppression of melanoma growth and induction of auto reactivity in mice. Cancer Immun 2: 1.

20. Roberts MS, Lorence RM, Groene WS, Bamat MK (2006) Naturally oncolytic viruses. Curr Opin Mol Ther 8(4): 314-321.

21. Yamamoto M, Davydova J, Wang M, Siegal GP, Krasnykh V, et al. (2003) Infectivity enhanced, cyclooxygenase-2 promoter-based conditionally replicative adenovirus for pancreatic cancer. Gastroenterology 125(4): 1203-1218.

22. Uma MM, Sudarsanam D (2012) Diabetes mellitus and recent advances. Res J Biotechnol 7: 2.

23. Wang W, Li W, Ma N, Steinhoff G (2013) Non-viral gene delivery methods. Curr Pharm Biotechnol 14(1): 46-60.

24. Roep BO, Solvason N, Gottlieb PA, Abreu JRF, Harrison LC, et al. (2013) Plasmid-encoded proinsulin preserves C-peptide while specifically reducing proinsulin-specific CD8+ T cells in Type 1 diabetes. Sci Transl Med 5(191): 191ra82. 


\section{Open Access Journal of Pharmaceutical Research}

25. Mitchell AM, Nicolson SC, Warischalk JK, Samulski RJ (2010) AAV's anatomy: Roadmap for optimizing vectors for translational success. Curr Gene Ther 10(5): 319-340.

26. Choi VW, McCarty DM, Samulski RJ (2005) AAV hybrid serotypes:Improved vectors for gene delivery. Curr Gene. Ther5(3): 299-310.

27. Rogers S, Pfuderer P (1968) Use of viruses as carriers of added genetic information. Nature 219 (5155): 749-751.
28. Bryant LM, Christopher DM, Giles AR, Hinderer C, Rodriguez JL, et al. (2013) Lessons learned from the clinical development and market authorization of Glybera. Hum Gene Ther Clin Dev 24(2): 55-64.

29. Gaudet D, Methot J, Dery S, Brisson D, Essiembre C, et al. (2013) Efficacy and long-term safety of alipogenetiparvovec (AAV1-LPLS447X) gene therapy for lipoprotein lipase deficiency: an open-label trial. Gene Ther 20(4): 361-369.

30. (2015) Advances in gene therapy, technology and market trends. Frost and Sullivan. 